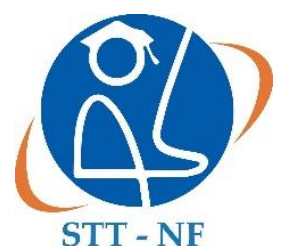

\author{
Jurnal Teknologi Terpadu \\ Journal of Integrated Technology \\ https://journal.nurulfikri.ac.id/index.php/JTT \\ ISSN : 2477-0043 ISSN ONLINE : 2460-7908
}

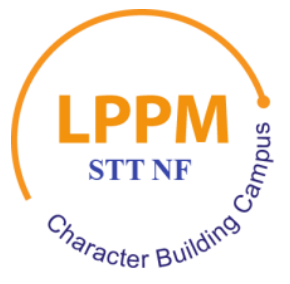

\title{
ANALISIS DAN IMPLEMENTASI SISTEM INFORMASI SDM MENGGUNAKAN SENTRIFUGO DI PESANTREN PETIK YBM PLN
}

\author{
Fauzi Hafsar, Rusmanto, Reza Aldiansyah \\ Sistem Informasi, STT Terpadu Nurul Fikri \\ Jakarta Selatan, DKI Jakarta, Indonesia \\ salmanalfauzi@gmail.com,rusmanto@gmail.com,reza.aldi@gmail.com
}

\begin{abstract}
Human Resources Information System (HRIS) is a utilization of Information Systems (IS) to help implementation of Human Resource Management. The Application of HR Management is used by Companies or Organizations in carrying out managerial functions such as managing employee data, evaluating employee performance, leave requests, service requests, and so on. Based on this, one of the Organizations namely Pesantren Information and Communication Technology Foundation Baitul Maal PLN (Pesantren PeTIK YBM PLN) wants to take advantage of the SISDM application to assist the running of managerial functions in his organization.. The aim of research is analyzing the process of HR Management in Pesantren PeTIK before the implementation of HRIS using sentrifugo so that it gets improvement after implementing sentrifugo in Pesantren PeTIK. The study has involved the descriptive quantitative analysist methode, where the primary data source was from some interviews and questionnaires. After the implementation of Sentrifugo, it is expected that the HRIS would be enhanced and transformed from manual to digitally centralized. Referring to the results of the research, there is a need to conduct further research on the implementation of sentrifugo at Islamic Boarding school of PeTIK (Pesantren PeTIK).
\end{abstract}

Keywords: HRIS, HR Management, Managerial Functions, Sentrifugo, Descriptive Quantitative Analysis.

\begin{abstract}
Abstrak
Sistem Informasi Sumber Daya Manusia (SISDM) merupakan pemanfaatan Sistem Informasi (SI) untuk membantu pelaksanakan Manajemen Sumber Daya Manusia (Manajemen SDM). Penerapan Manajemen SDM ini dimanfaatkan perusahaan atau organisasi dalam menjalankan fungsi managerial seperti halnya mengelola data pegawai, penilaian kinerja pegawai, permintaan cuti, permintaan layanan, dan lain sebagainya. Berdasarkan hal tersebut, salah satu organisasi yaitu Pesantren Teknologi Informasi dan Komunikasi Yayasan Baitul Maal PLN (Pesantren PeTIK YBM PLN) hendak memanfaatkan aplikasi SISDM tersebut guna membantu jalannya fungsi manajerial di organisasinya. Penelitian ini bertujuan untuk menganalisis proses manajemen SDM di Pesantren PeTIK sebelum diimplementasikannya SISDM menggunakan sentrifugo sehingga mendapatkan perbaikan setelah mengimpelementasikan sentrifugo di Pesantren PeTIK. Penelitian dilakukan menggunakan metode analisis kuantitatif deskriptif, dimana sumber data primer berasal dari wawancara dan kuesioner. Setelah diterapkannya sentrifugo, diharapkan adanya perbaikan sistem SDM dari manual menjadi digital dan tersentral. Merujuk kepada hasil penelitian tersebut, ke depannya perlu dilakukannya penelitian lebih lanjut tentang implementasi sistem informasi SDM dengan sentrifugo di PeTIK
\end{abstract}

Kata Kunci: SISDM, Manajemen SDM, Fungsi Manajerial, Sentrifugo, Analisis Kuantitatif Deskriptif. 


\section{PENDAHULUAN}

\subsection{Latar Belakang}

Sistem Informasi Sumber Daya Manusia (SISDM) merupakan Sistem Informasi yang dimanfaatkan perusahaan atau organisasi dalam menjalankan fungsi manajerial seperti halnya mengelola data pegawai, penilaian kinerja pegawai, permintaan cuti, permintaan layanan, dan lain sebagainya [1].

Manajemen Sumber Daya Manusia / MSDM merupakan pengakuan tentang pentingnya tenaga kerja organisasi sebagai sumber daya manusia yang sangat penting dalam memberi kontribusi bagi tujuan-tujuan organisasi, dan penggunaan beberapa fungsi dan kegiatan untuk memastikan bahwa SDM tersebut digunakan secara efektif dan adil bagi kepentingan individu, organisasi dan masyarakat [2]

Berdasarkan penjelasan tersebut, penulis melakukan peninjauan studi literatur dengan merujuk kepada salah satu karya ilmiah [3] dimana hasil penelitian tersebut merupakan Laporan Tugas Akhir tentang Sentrifugo yang memiliki tujuan penelitian Untuk mengotomatisasi proses dan meningkatkan efisiensi pekerjaan bagi Organisasi Pakistan Air. Selain itu, hasil dari penelitian yang telah dilakukannya adalah Terciptanya sistem manajemen karyawan berbasis $w e b$ di Pakistan Air.

Atas pernyataan tersebut Sentrifugo mampu menjadi sistem manajemen karyawan di suatu organisasi. Penulis melakukan penelitian yang memiliki keterkaitan erat terhadap sumber rujukan. Adapun dengan tujuan untuk menerapkan salah satu fungsi manajerial disebuah organisasi yaitu penilaian kinerja karyawan. Salah satu organisasi yaitu Pesantren Teknologi Informasi dan Komunikasi Yayasan Baitul Maal PLN (Pesantren PeTIK YBM PLN) PeTIK [4], hendak memanfaatkan aplikasi SISDM tersebut guna membantu jalannya fungsi manajerial di Organisasinya.

Diketahui bahwa, penilaian kinerja pegawai Pesantren PeTIK saat ini menggunakan sistem penilaian manual tidak dengan menggunakan aplikasi, akan tetapi dengan metode penilaian grading dan multi rater. Metode penilaian tersebut merupakan metode penilaian kinerja pegawai dengan menggolongkannya ke dalam kategori yang sudah disepakati. Penerapan penilaian tersebut dilakukan setahun sekali dengan menilai diri sendiri, atasan langsung dan tim penilai.

\subsection{Rumusan Masalah}

Berdasarkan penjelasan yang telah diuraikan, ada beberapa rumusan masalah yang dianalisis oleh penulis, yakni :

1. Bagaimana proses Manajemen SDM Pesantren PeTIK khususnya pada proses penilaian pegawai sebelum diterapkannya sentrifugo?

2. Bagaimana proses implementasi sentrifugo di Pesantren PeTIK?

3. Apa perbaikan yang didapatkan manajemen PeTIK setelah mengimplementasikan SISDM dengan sentrifugo?

\subsection{Tujuan}

Tujuan yang ingin dicapai dari penelitian ini yaitu:

1. Mengetahui hasil analisis proses manajemen SDM yaitu proses penilaian kinerja yang ada di Pesantren PeTIK.

2. Mengimplementasikan sentrifugo di Pesantren PeTIK.

3. Mengetahui hasil dari perbaikan yang didapatkan oleh manajemen PeTIK setelah mengimplementasikan sentrifugo di Pesantren PeTIK.

\subsection{Manfaat}

Manfaat yang akan dihasilkan dari penelitian adalah sebagai berikut:

1. Memberikan kemudahan kepada manajer atau pegawai dalam menjalankan proses Manajemen SDM.

2. Memperoleh manfaat berupa informasi akan kinerja yang dimiliki oleh setiap pegawai dengan melakukan proses penilaian kinerja antarpegawai.

\section{METODE}

\subsection{Tahapan Penelitian}

Tahapan penelitian yang dilakukan oleh penulis digambarkan pada gambar 2.1. Adapun penjelasan tahapan tersebut adalah:

\subsubsection{Studi Pendahuluan}

Tahapan pertama yang dilakukan adalah studi pendahuluan. Studi pendahuluan memiliki dua sub proses berbeda yang dapat diuraikan sebagai berikut:

\section{a. Studi Literatur}

Studi literatur adalah proses mengumpulkan informasi dari berbagai sumber yaitu jurnal, dan hasil penelitian lain yang terkait dengan penelitian yang dilakukan ini. 
b. Studi Lapangan

Studi Lapangan adalah proses yang dilakukan dengan melakukan observasi terhadap objek penelitian sehingga dapat diketahui permasalahan yang terdapat di lapangan.

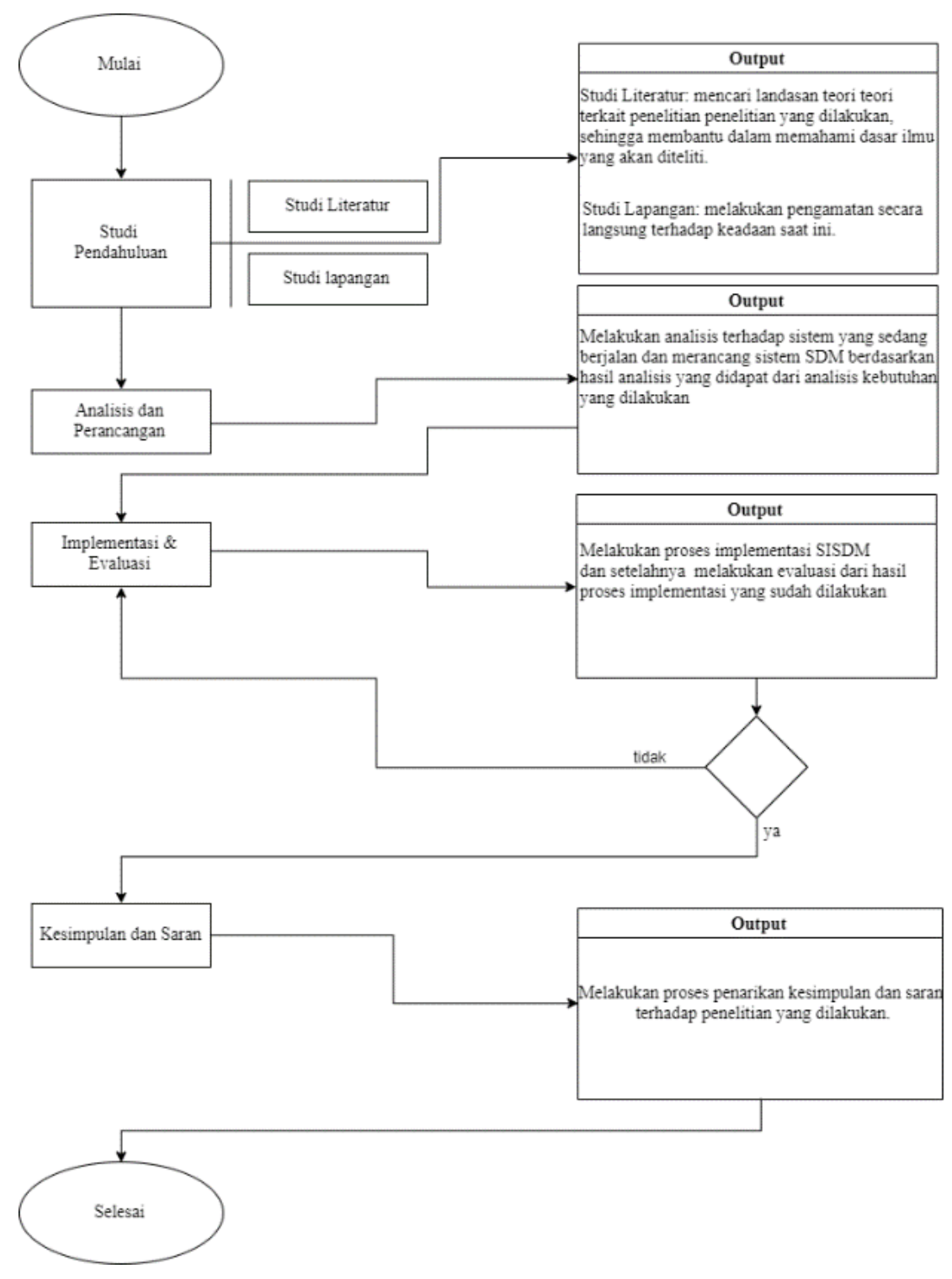

Gambar 1 Tahapan Penelitian

\subsubsection{Analisis dan Perancangan}

Tahapan ini dilakukan dengan melakukan analisa terhadap kondisi saat ini terhadap objek penelitian, sehingga dapat diketahui permasalahan yang dihadapi saat ini, serta merancang solusi atas analisa permasalahan yang telah dilakukan.

\subsubsection{Implementasi dan Evaluasi Sistem}

Tahapan ini dilakukan dengan menerapkan hasil rancangan yang sebelumnya telah dirumuskan.
Proses penerapan ini dilakukan dengan disertai proses evaluasi.

Tahapan evaluasi sendiri dilakukan mengetahui hasil dari tahapan penerapan yang telah dilakukan.

\subsubsection{Kesimpulan dan Saran}

Setelah perapan dan evaluasi dilakukan, selanjutnya adalah melakukan penarikan kesimpulan dan saran atas proses tersebut. 


\subsection{Jenis Penelitian}

Jenis penelitian yang digunakan adalah penelitian implementasi SISDM menggunakan aplikasi sentrifugo yang diterapkan di Pesantren PeTIK YBM PLN.

\subsection{Lingkungan Pengembangan}

Penelitian ini dilakukan oleh penulis di Pesantren PeTIK YBM PLN, Jl. Mandor Basar No.54 Rangkapanjaya Pancoran Mas, Depok 16435

\subsection{Alat dan Bahan}

Adapun alat dan bahan yang dibutuhkan dalam penelitian ini, antara lain :

1. Laptop

Dipergunakan untuk melakukan percobaan terhadap aplikasi

2. Sentrifugo 3.2

Aplikasi SISDM yang digunakan selama proses penelitian berlangsung

3. LAMPP (Linux Apache, MySQL, PHP dan Perl) Aplikasi Web Server yang bisa dijalankan di komputer lokal

4. Linux OS 18.04 (Server)

Perangkat yang digunakan dalam proses implementasi

5. Gadget (notes, tethering, chat)

Digunakan untuk menyimpan hasil wawancara, menambatkan jaringan internet, dan untuk sarana komunikasi

\section{URAIAN PENELITIAN}

3.1 Studi Pendahuluan

Pada tahapan ini, kegiatan yang dilakukan yaitu berupa studi pendahuluan. Studi pendahuluan sendiri membagi ke dalam dua jenis tahapan, yang masing-masing jenis studi yaitu sebagai berikut:

\subsubsection{Studi Literatur}

Studi literatur dilakukan dengan mengumpulkan berbagai informasi dari berbagai sumber karya ilmiah seperti jurnal, dan hasil penelitian lain yang terkait dengan penelitian ini dalam rentan waktu tiga hingga lima tahun sebelumnya. Seperti halnya teori manajemen SDM, teori SISDM, dan teori lainya.

\subsubsection{Studi Lapangan}

Studi Lapangan dilakukan dengan melakukan pengamatan dengan melakukan wawancara. Wawancara dilakukan sejak penelitian ini dimulai sekitar bulan jui tahun 2019. Bentuk dari wawancara yang dilakukan terdapat beberapa macam diantaranya yaitu wawancara secara offline dengan mengajukan beberapa pertanyaan secara langsung kepada kepala SDM Pesantren PeTIK dan wawancara online yaitu dengan meminta kesediaannya untuk mengisi questioner yang dikirimkan berupa soft file dari beberapa pertanyaan yang sudah ada.

\subsubsection{Analisis dan Perancangan}

Tahapan ini penulis melakukan kegiatan berupa analisis terhadap sistem yang sedang berjalan di PeTIK dengan melaksanakan wawancara kepada bagian SDM di PeTIK, sehingga dapat diketahui hasil berupa permasalahan yang dihadapi saat ini terhadap sistem yang berjalan saat ini. Serta merancang Sistem sesuai dengan hasil yang diperolah dari melakukan analisis terhadap sistem yang berjalan saat ini.

\subsubsection{Implementasi dan Evaluasi Sistem}

Pada tahapan ini penulis melakukan proses implementasi terhadap sistem yang telah dirancang. Kegiatan yang terkandung dalam tahapan ini di antaranya adalah instalasi aplikasi SISDM (yang telah dilakukan) dan dilanjutkan dengan melakukan uji coba terhadap sistem seperti halnya memasukkan data pegawai ke dalam sistem dan menggunakan data pegawai tersebut pada modul yang dilakukan pada penelitian ini. Selanjutnya melakukan evaluasi terhadap uji coba yang dilakukan terhadap sistem tersebut untuk dapat mengetahui hasil dari proses uji coba yang dilakukan telah berjalan dengan baik dan sesuai harapan. Proses uji coba yang dilakukan ini adalah dengan menggunakan aplikasi sentrifugo, pada komputer server yang PeTIK miliki.

\subsubsection{Kesimpulan dan Saran}

Setelah dilakukannya uji coba, penulis dapat memberikan penarikan kesimpulan dan saran atas proses uji coba yang telah dilakukan.

\section{ANALISIS DAN PERANCANGAN}

\subsection{Analisis Masalah}

Pada bahasan ini menjelaskan terkait hasil studi lapangan yang didapat penulis setelah melakukan wawancara dengan pihak manajer SDM Pesantren PeTIK. Diketahui bahwa penilaian kinerja pegawai Pesantren PeTIK saat ini menggunakan sistem penilaian manual tidak dengan menggunakan aplikasi, akan tetapi dengan metode penilaian grading dan multi rater. Metode penilaian tersebut merupakan metode penilaian kinerja pegawai dengan menggolongkannya ke dalam kategori yang sudah disepakati. Penerapan penilaian tersebut dilakukan setahun sekali dengan menilai diri sendiri, atasan langsung dan tim penilai. Seperti gambar berikut: 


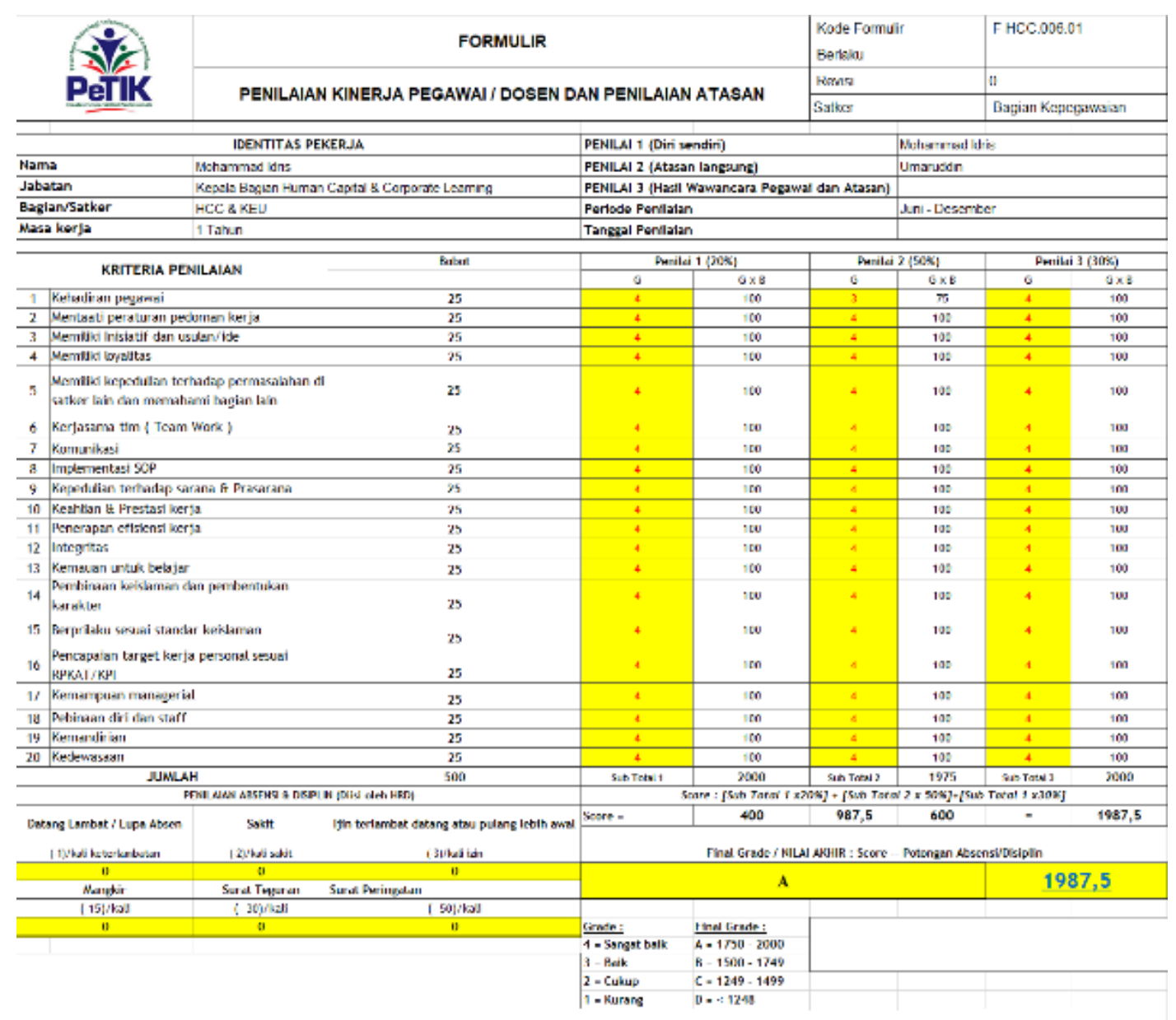

Gambar 2. Penilaian Kinerja Pegawai Di Pesantren PeTIK

\subsection{Software Requirement Specification (SRS)}

Bahasan kali ini akan menjelaskan terkait fungsi fungsi apa saja yang terdapat pada aplikasi sentrifugo HRIS sentrifugo [5]. Penjelasan tersebut dipaparkan melalui Software Requirement Specification (SRS) diantaranya sebagai berikut

\begin{tabular}{|l|l|}
\hline \multicolumn{1}{|c|}{ SRS-ID } & \multicolumn{1}{|c|}{ DESKRIPSI KEBUTUHAN FUNGSIONAL } \\
\hline SRS-F-001 & Admin dapat menambahkan data pegawai pada aplikasi \\
\hline SRS-F-002 & Admin dapat melihat data pegawai pada aplikasi \\
\hline SRS-F-003 & Admin dapat mengubah data pegawai pada aplikasi \\
\hline SRS-F-004 & Admin dapat mengatur role pegawai \\
\hline SRS-F-005 & Admin dapat menginisiasi penilaian dalam Aplikasi \\
\hline SRS-F-006 & Admin dapat menentukan metode penilaian dalam aplikasi \\
\hline SRS-F-007 & Admin dapat menentukan parameter penilaian \\
\hline SRS-F-008 & Admin dapat melakukan validasi inisiasi penilaian \\
\hline SRS-F-009 & Atasan dapat memberikan penilaian \\
\hline SRS-F-010 & Atasan dapat melakukan validasi penilai \\
\hline SRS-F-011 & Atasan dapat melakukan cetak hasil penilaian \\
\hline SRS-F-012 & Pegawai memberikan penilaian \\
\hline SRS-F-013 & Pegawai melakukan validasi terhadap penilaian \\
\hline SRS-F-014 & Pegawai dapat melakukan cetak terhadap hasil penilaian \\
\hline
\end{tabular}

Gambar 3. SRS Sistem 


\subsection{Use Case Diagram}

Use case diagram utama menggambarkan aktivitas pada kegiatan implementasi sistem informasi SDM menggunakan sentrifugo dalam proses penilaian kinerja pegawai. Use case diagram tersebut digambarkan pada gambar 4.3

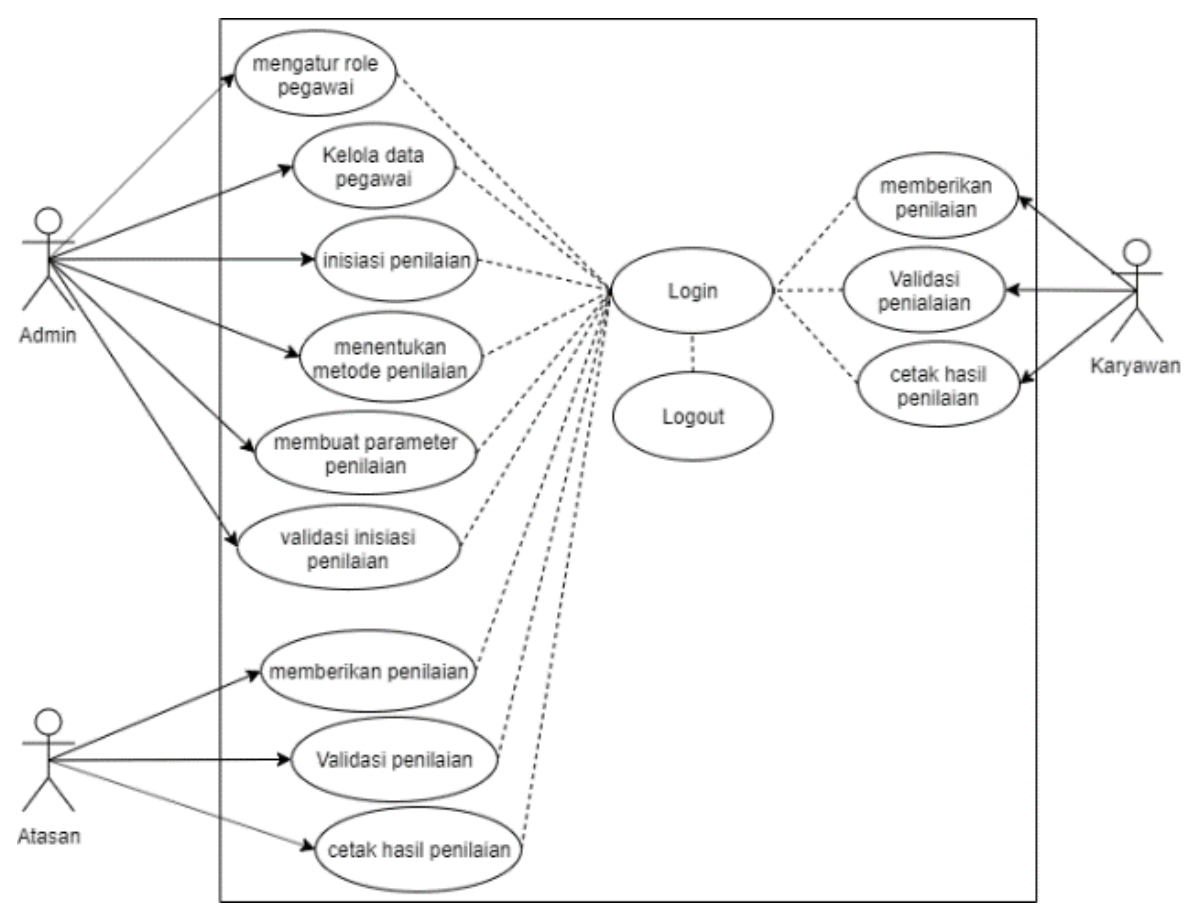

Gambar 4. Use Case Diagram

\section{IMPLEMENTASI DAN EVALUASI}

Tampilan dari aplikasi pada bagian penilaian kinerja karyawan ditampilkan pada gambar 5.1.

Pada gambar 5.1 merupakan proses pengujian terhadap aplikasi sentrifugo yang dapat dijelaskan sebagai berikut :

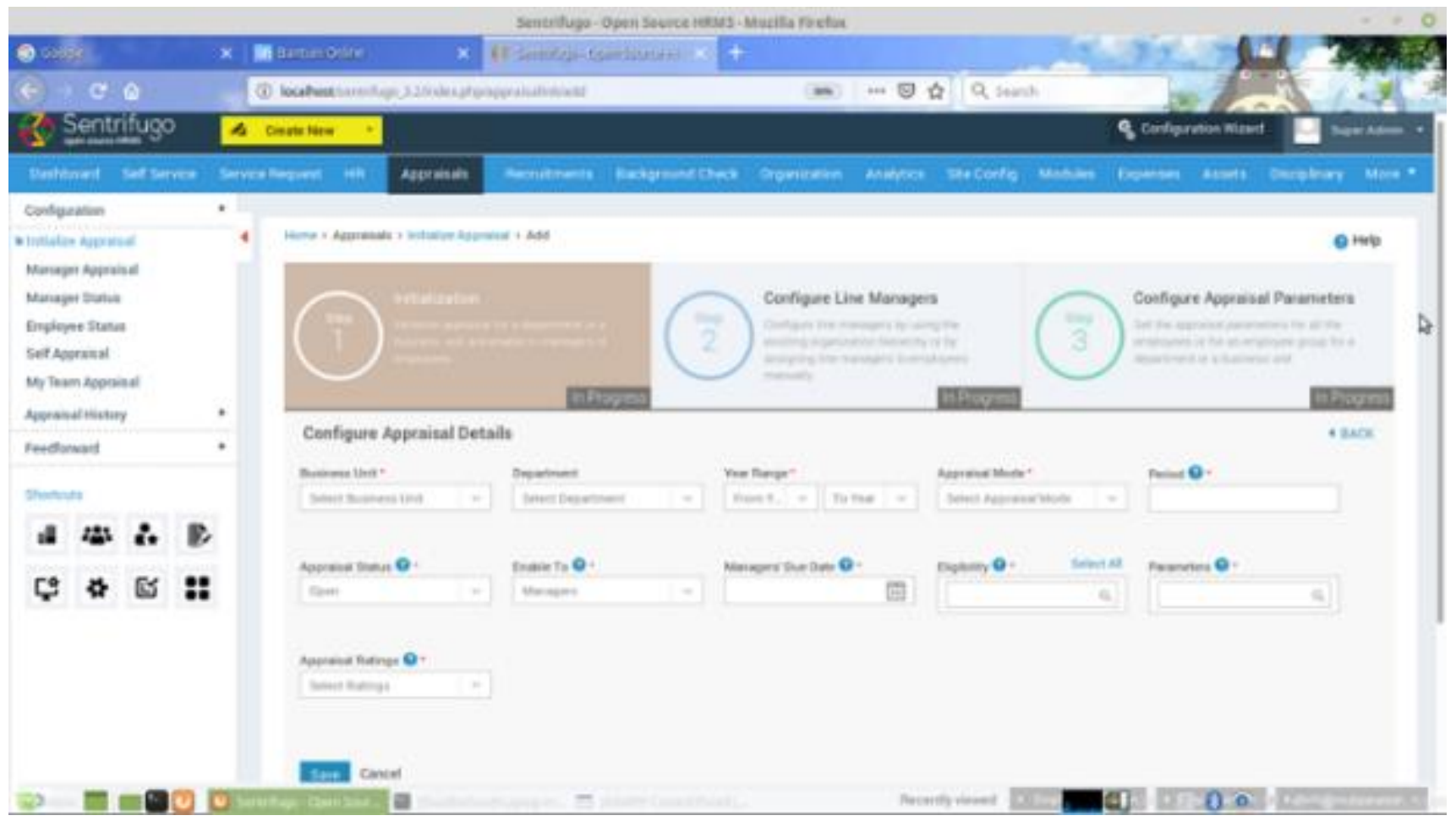

Gambar 5. Menu penilaian kinerja karyawan 


\subsection{Alur Penilaian Kinerja}

Alur penilaian kerja pada aplikasi sentrifugo dijelaskan dalam beberapa tahap berikut :

1. Buka browser $\rightarrow \quad$ akses http://localhost/sentrifugo_3.2/indexs.php/ $\rightarrow$ masukan username dan password $\rightarrow$ klik " $L O G$ $I N " \rightarrow$ tampil Dashboard $\rightarrow$ klik menu "Appraisals" $\rightarrow$ tampil form penilaian kinerja $\rightarrow$ mengisi form penilaian kinerja $\rightarrow$ klik "save as draft" $\rightarrow$ tampil draft penilaian kinerja sementara.

2. Dashboard $\rightarrow$ klik menu "Appraisals" $\rightarrow$ tampil draft penilaian kinerja $\rightarrow$ edit untuk menambahkan deskripsi penilaian kinerja $\rightarrow$ klik "send to line manager" $\rightarrow$ klik "print" $\rightarrow$ dokumen akan langsung tercetak $\rightarrow$ Klik account user $\rightarrow$ klik "logout".

\subsection{Evaluasi dan Rekomendasi}

\subsubsection{Evaluasi}

Berdasarkan proses implementasi aplikasi sentrifugo yang dilakukan di Pesantren PeTIK YBM PLN dapat diketahui bahwa:

1. Proses implementasi yang dilakukan tidak menemui kesalahan ataupun gangguan pada saat melakukan implementasi aplikasi, juga pada saat melakukan proses penilaian kinerja karyawan.

2. Hasil wawancara peneliti dengan manajemen PeTIK setelah pengimplementasian aplikasi sentrifugo, didapatkan informasi adanya perbaikan manajemen SDM, antara lain :

a) Tersentralisasinya data induk karyawan ke sistem database yang terkomputerisasi atau digitalisasi sehingga mempermudah untuk mencari data serta mengakses data yang dibutuhkan Pesantren PeTIK.

b) Ada proses penilaian kinerja karyawan, data penilaian bisa dilakukan kapanpun dan di manapun. Data tidak dapat diubah oleh pihak manapun secara manual dan manajemen PeTIK mampu mengukur hasil kerja berdasarkan komponen penilaian yang tersedia.

\subsubsection{Rekomendasi}

Berdasarkan pada proses implementasi aplikasi sentrifugo yang dilakukan di Pesantren PeTIK YBM PLN, rekomendasi yang penulis berikan berupa tahapan mapun langkah yang dapat diterapkan oleh Pesantren PeTIK yaitu :

1. Integrasi modul pengajuan cuti pegawai pada sentrifugo dengan proses pengajuan cuti yang ada di Pesantren PeTIK.
2. Integrasi modul absensi pada sentrifugo dengan perangkat absesnsi di pesantren PeTIK.

3. Integrasi modul penggajian pada sentrifugo dengan sistem Penggajian yang ada di Pesantren PeTIK.

\section{KESIMPULAN DAN SARAN}

\subsection{Kesimpulan}

Setelah penelitian ini selesai dilakukan, penulis dapat memberikan kesimpulan bahwa:

1. Proses penilaian kinerja pegawai sebelum diterapkannya sentrifugo di Pesantren PeTIK yaitu dengan menggunakan file kertas. Hal tersebut didukung juga dengan hasil analisis terhadap proses Manajemen SDM di Pesantren PeTIK berupa print out dokumen penilaian kinerja pegawai yang didapatkan dari hasil studi lapangan.

2. Proses implementasi sentrifugo di Pesantren PeTIK adalah sebagai berikut:

a. Langkah pertama yang dilakukan ialah analisis kebutuhan terdahap sistem guna melakukan proses perancangan yang diperlukan untuk mengidentifikasi sistem yang dibutuhkan

b. Langkah berikutnya, proses implementasi tersebut dapat dilakukan dengan beberapa tahapan, diantaranya instalasi, konfigurasi, pengujian oleh penulis dan pengujian yang juga dilakukan oleh pengguna.

3. Berdasarkan kepada hasil wawancara yang dilakukan guna mengetahui hasil dari perbaikan yang didapatkan oleh manajemen PeTIK setelah mengimplementasikan sentrifugo di Pesantren PeTIK adalah

a. Tersentralisasinya data induk pegawai ke dalam sistem database di Pesantren PeTIK.

b. Proses penilaian yang fleksibel (bisa kapan dan dimana saja) dan menjamin keaslian terhadap data yang ada.

4. Tersedianya kode sumber (Open Source), sentrifugo dapat dikembangkan lebih lanjut untuk memaksimalkan penggunaannya.

\subsection{Saran}

Meskipun penerapan sentrifugo SISDM telah dapat membantu Pesantren PeTIK dalam mengelola SDM khususnya proses penilaian kinerja pegawai, namun penulis belum membahas modul - modul lain dari sentrifugo, sehingga penulis memberikan saran penelitian lebih lanjut tentang implementasi sistem informasi SDM dengan sentrifugo di PeTIK untuk modul pengajuan cuti pegawai, modul absensi, dan modul penggajian. 


\section{DAFTAR PUSTAKA}

[1] T. Sutabri, Konsep Sistem Informasi. Yogyakarta: Andi Publisher, 2012.

[2] Priyono, Manajemen Sumber Daya Manusia. Sidoarjo: Zifatama Publisher, 2019.

[3] A. Shakoor, "Sentrifugo Final Project Report," 2017.

[4] A. PeTIK, "Sejarah PeTIK," 2018. [Online]. Available: https://petik.or.id/sejarah. [Accessed: 20-Jun-2020].

[5] "Sentrifugo: Open Source HRMS," Sapplica, 2020. [Online]. Available: http://www.sentrifugo.com/. 